\title{
The vegetation of the cretaceous outcrops of Novhorod-Siverskyi Polesie loess "islands" (Ukraine) and the new locality of Gentiana cruciata L.
}

\author{
Oleksandr Lukash ${ }^{1, *}$, Iryna Miroshnyk ${ }^{2}$, Oleksandr Yakovenko ${ }^{1}$, Svitlana Strilets ${ }^{2}$
}

\begin{abstract}
${ }^{1}$ Department of Ecology and Nature Conservation, ${ }^{2}$ Department of Languages and Methodology,
T. Shevchenko National University "Chernihiv Collegium", Hetman Polubotko Str., 53, 14013, Chernihiv, Ukraine,

*e-mail: lukash2011@ukr.net
\end{abstract}

Received: 21 December 2018 / Accepted: 22 February 2019

\begin{abstract}
The vegetation of the cretaceous outcrops of Novhorod-Siverskyi Polesie loess "islands" is represented by the grasslands communities of the Artemisietea vulgaris Lohmeyer et al. in Tx. ex von Rochow1951, Festuco-Brometea Br.-Bl. et Tx. ex Soó 1947, Trifolio-Geranietea sanguinei T. Müller 1962 classes and shrubby phytocoenoses of the Robinietea Jurko ex Hadač et Sofron 1980 class. The structure and composition of the plant communities are influenced by the degree of anthropogenic influence (both in the past and present) on the ecosystems of cretaceous outcrops. The determining anthropogenic factors contributing to the formation of the ruderal communities were chalk mining and gardening. The influence of erosive processes is manifested in the spatial delimitation of plant communities of various syntaxonomic belongings. The anthropogenic successional communities: semiruderal grasslands and herblands of the immoral and subboreal zones of Europe (Convolvulo-Agropyretum repentis Felföldy (1942) 1943, Poo compressaeTussilaginetum farfarae R. Tx. 1931) and scrub communities of temperate Europe, represented by the Elytrigio repentis-Robinietum Smetana 2002 phytocoenoses typical for Steppe zones, prevail. Semixerothermic communities were found on the steep slopes of the cretaceous outcrops (eastern and southwestern expositions) - early successional stages with a significant amount of the characteristic species of the Festuco-Brometea Br.-Bl. et Tx. ex Soó 1947 class. On the cretaceous outcrops of Novhorod-Siverskyi Polesie loess "islands" the communities of Trifolion medii T. Müller 1962 (meso-subxerophytic fringe phytocoenoses on nutrient-poor but base-rich soils at lower altitudes of temperate Western and Central Europe) is localized on the slopes of the eastern and southeastern parts of the expositions which do not undergo anthropogenic influence and are separated by erosion forms. Such conditions were favorable for preserving the Gentiana cruciata L. relict species in this locality. The population of this species was found in the area of $50 \mathrm{~m}^{2}$ in the Trifolio medii-Agrimonietum Th. Müller 1962 association community and represented by two compact groups of individuals (the area of $0.5 \mathrm{~m}^{2}$ each) and individual plants. In order to preserve the habitat of this rare species, it is worth creating here a reserve.
\end{abstract}

Keywords: Polesie, cretaceous outcrops, loess "islands", plant communities, syntaxonomy, successional stages, rare plant species, anthropogenic impact.

\section{Introduction}

Among other Polesie districts, Novhorod-Siverskyi Polesie is characterized by the considerable dismemberment and outcrop of indigenous sediments. This imposes an imprint on the vegetation cover of the territory. The ecological and phytoindicative study of the plant communities of cretaceous outcrops of the Desna River right bank was carried out in the outskirts of the Kamin, Pushkari, Rohivka villages of the Novhorod-Siverskyi district, Chernihiv region (Savon \& Lysenko, 2001). Our research covered the area located to the south of the earlier studies: in the 
outskirts of the Putyvsk, Yukhnove and Horky villages. The goal of our study was to determine the composition of plant communities of cretaceous outcrops of NovhorodSiverskyi Polesie, to find out their syntaxonomic affiliation and floristic features. The working hypotheses of the research: the cretaceous outcrops of Novhorod-Siverskyi Polesie are the potential places of formation of the xerothermic and semixerothermic grass communities and the habitats of rare plant species, characterizing these communities. One of such species is Gentiana cruciata L. - the object of the population modelling the spatial interactions between plants and insects (Clarke et al., 1998).

\section{Study area}

The investigated area (Fig. 1A) covers the zone with the largest dismemberment and and outcrop of root sediments along the right bank of the meridial part of the Desna River with the outcrops of indigenous sediments from the right bank of the lower part of the Sudost river to the turn of the Desna River to the southwest. The Desna River valley and its right bank tributaries, gullies, ravines cut the whole thickness of anthropogenic and paleogene sediments and penetrate deeply into the thickness of cretaceous sediments. In the thickness of cretaceous sediments in the right bank of the slopes of the Desna valley dark gray marls, limestone glauconitic sands and white chalk are outcropped. The surface of cretaceous sediments carries the marks of intense erosive dismemberment. The variation of absolute marks is from 125 to $165 \mathrm{~m}$ (Marynich, 1968).

In some parts paleogene sediments are partially blurred and anthropogenic sediments lie directly on chalky rocks. The lower layer of the anthropogenic strata is moraine. Moraine often lays the slopes of the right tributaries of the Desna River and its large gullies. The valleys of the right bank tributaries of the Desna River divide the explored area into several loess "islands": Rohovskyi, NovhorodSiverskyi, Blystovitskyi, Ponornytskyi. The last ones are the continuation of the loess "islands" of Chernihiv Polesie, which are characterized by a greater degree of synanthropy of the vegetation cover (Lukash et al., 2018).

In the hypsometric plane, the territory is an elevated plain, absolute markings of which exceed $200 \mathrm{~m}$. The ex-

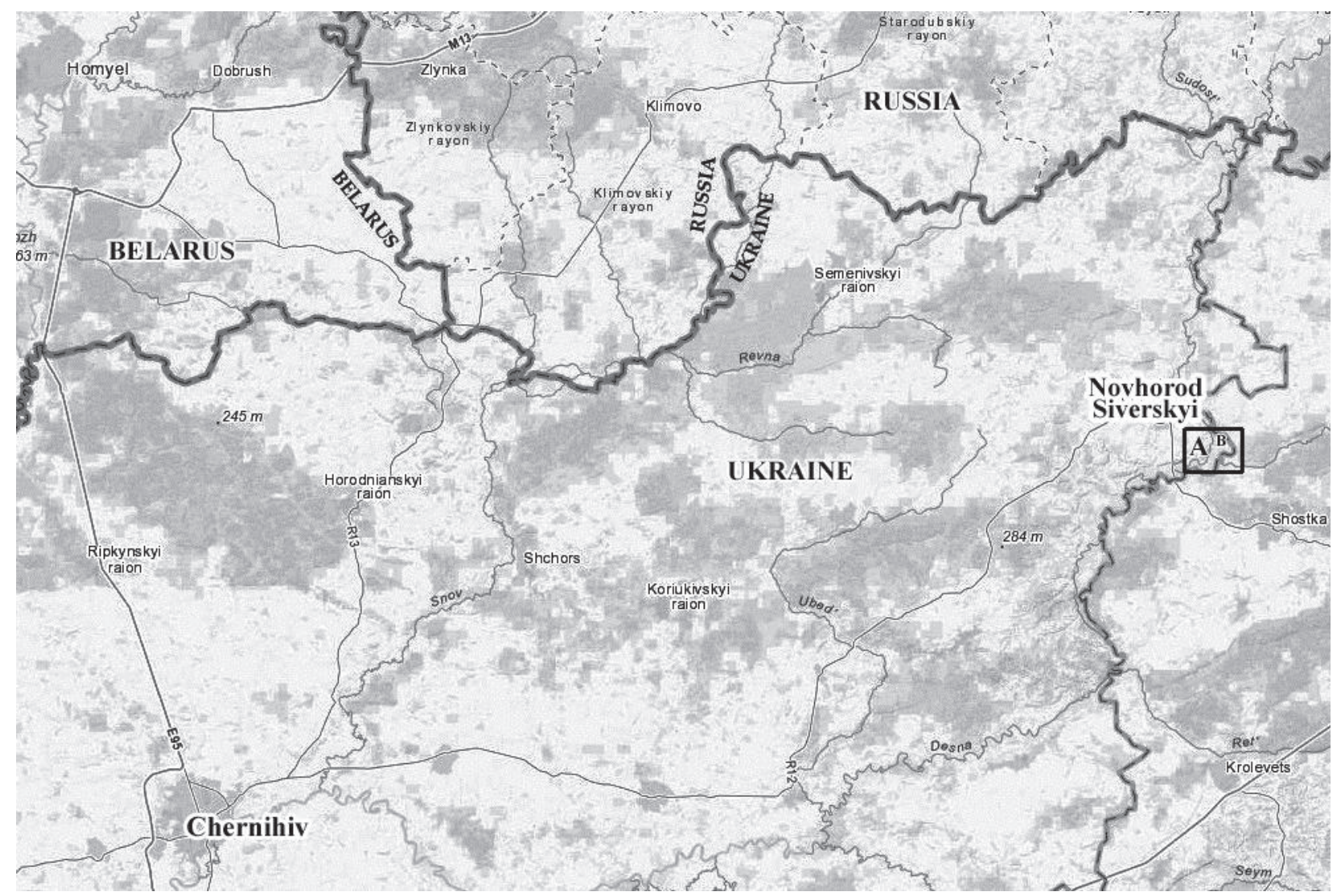

Figure 1. Location of the cretaceous outcrops of Novhorod-Siverskyi Polesie loess "islands" (the square marked as "A") 
cess of the Desna is $100-105 \mathrm{~m}$. The proximity of the deep local base of erosion and the fact that the loess cover is easily eroded is the main cause of the exclusive development of the ravine and gully network, the density of which exceeds $1 \mathrm{~km} / \mathrm{km}^{2}$. The meadow-steppe and synanthropic vegetation is well represented on the slopes of the ravines and gullies.

\section{Material and methods}

The materials for the article were collected during the field research of the loess "islands" of Novhorod-Siverskyi Polesie during 2006-2018. The field study of the vegetation was carried out by geobotanical methods (Korchahin, 2012). The vegetation descriptions were carried out during theoptimum of vegetation period in the areas of $30-50 \mathrm{~m}^{2}$. The exposition and steepness of the slopes, the general projective coverage of the vegetation community and the coverage of each species were noted Cover abundance scale is the following: + - up to $1 \%, 1-1-5 \%, 2-6-15$, $3-16-25 \%, 4-26-50 \%, 5>50 \%$. 25 phytosociological relevés were taken. Syntaxa were identified according to Mucina et al. (2016), Matuszkiewicz (2001) (for natural vegetation), Solomakha et al. (1992) (for synanthropic vegetation), Brzeg (2005) (for Trifolio-Geranietea sanguinei communities). Syntaxa names are ordered according to Mucina et al. (2016). The successional stages of vegetation are named by the dominant species.

\section{Results and discussion}

A generalized scheme of the vegetation of the cretaceous outcrops of Novhorod-Siverskyi Polesie loess "islands" is the following:

Class: Artemisietea vulgaris Lohmeyer et al. in Tx. ex von Rochow1951

Order: Agropyretalia intermedio-repentis T. Müller et Görs 1969
The group of semiruderal alliances

Alliance:Convolvulo arvensis-Agropyrion repentis Göors 1967

Association: Convolvulo-Agropyretum repentis Felföldy (1942) 1943

Association: Falcario vulgaris-Agropyretum repentis Müller et Görs 1969

Association: Poo compressae-Tussilaginetum farfarae R. Tx. 1931

Class: Festuco-Brometea Br.-Bl. et Tx. ex Soó 1947

The group of orders of sub-xeric steppic grasslands

Order: Brachypodietalia pinnati Korneck 1974

Iinitial community: Chamaecytisus ruthenicus-Aster amellus [Cirsio-Brachypodion pinnati Hadač et Klika in Klika et Hadač 1944 + Molinio-Arrhenatheretea Tx. 1937+Trifolio-Geranietea sanguinei T. Müller 1962]

Iinitial community Elytrigia intermedia-Salvia pratensis [Cirsio-Brachypodion pinnati Hadač et Klika in Klika et Hadač 1944 + Molinio-Arrhenatheretea Tx. 1937 + Trifolio-Geranietea sanguinei T. Müller 1962]

Initial community Origanum vulgare purum [CirsioBrachypodion pinnati Hadač et Klika in Klika et Hadač $1944+$ Molinio-Arrhenatheretea Tx. $1937+$ Trifolio-Geranietea sanguinei $\mathrm{T}$. Müller 1962]

Class: Trifolio-Geranietea sanguinei T. Müller 1962

Order: Origanetalia T. Müller 1962

Alliance: Trifolion medii T. Müller 1962

Association: Trifolio medii-Agrimonietum Th. Müller 1962

Class: Robinietea Jurko ex Hadač et Sofron 1980

Order: Chelidonio-Robinietalia Hadač et Sofron 1980

Alliance: Balloto nigrae-Robinion pseudoacaciae Hadač et Sofron 1980

Association: Elytrigio repentis-Robinietum Smetana 2002.

Relevés 1-14 (Table 1) belong to the Convolvulo arvensis-Agropyrion repentis association from the Agropyretalia intermedio-repentis order of the Artemisietea vulgaris class. The cenoses of the Convolvulo-Agropyretum repentis association occupy the largest areas on the cretaceous sediments (Fig. 2B). 


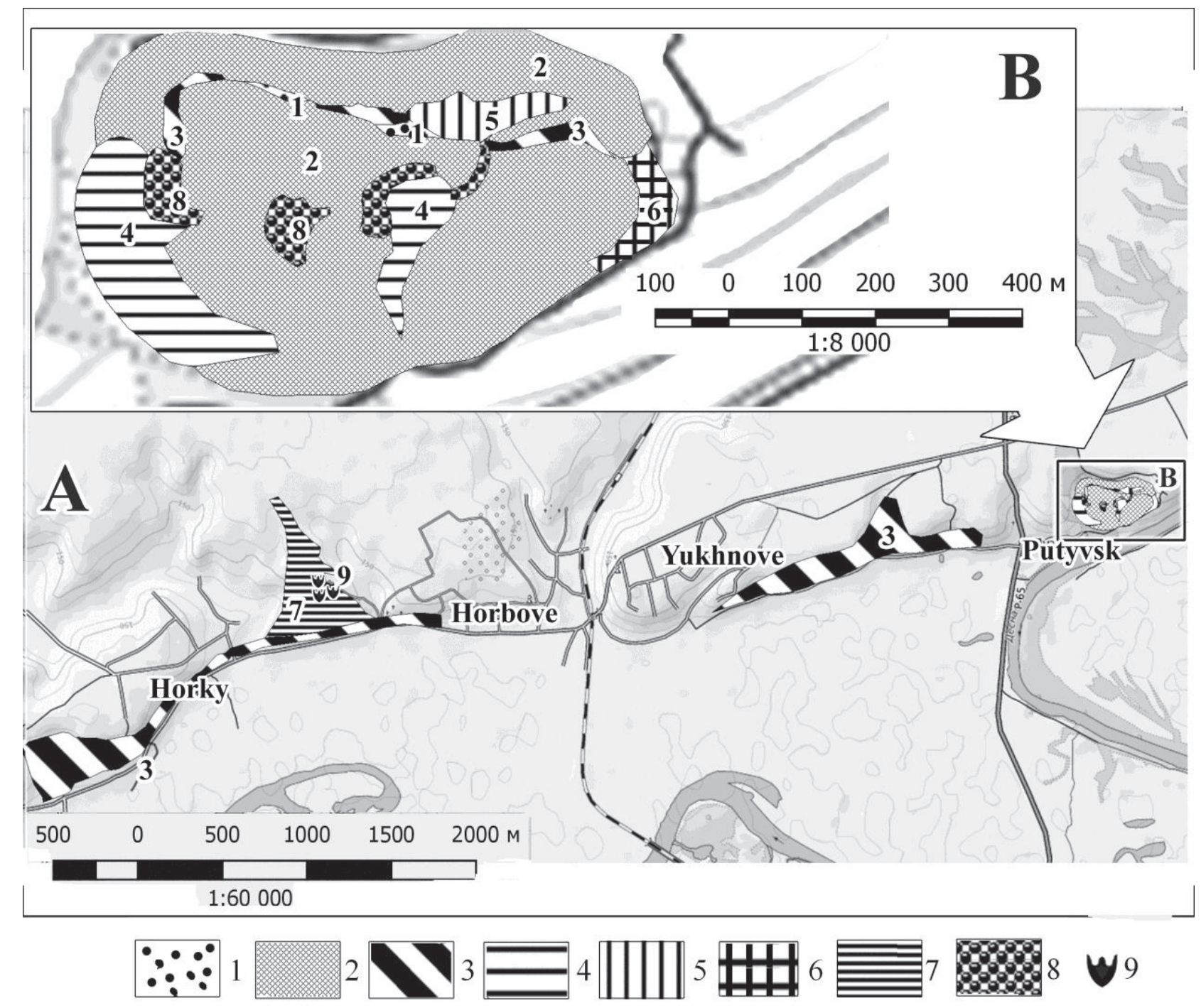

Figure 2. Mapping of the vegetation of the cretaceous outcrops of Novhorod-Siverskyi Polesie loess "islands". Syntaxon (1-8): 1 - Falcario vulgaris - Agropyretum repentis, 2 - Convolvulo arvensis - Agropyretum repentis, 3 - Poo compressae-Tussilaginetum farfarae, 4 - Chamaecytisus ruthenicus - Aster amellus, 5-Elytrigia intermedia-Salvia pratensis, 6 - Origanum vulgare purum, 7 - Trifolio medii-Agrimonietum, 8 - Elytrigio repentis-Robinietum; 9 - the habitat of Gentiana cruciata L. 


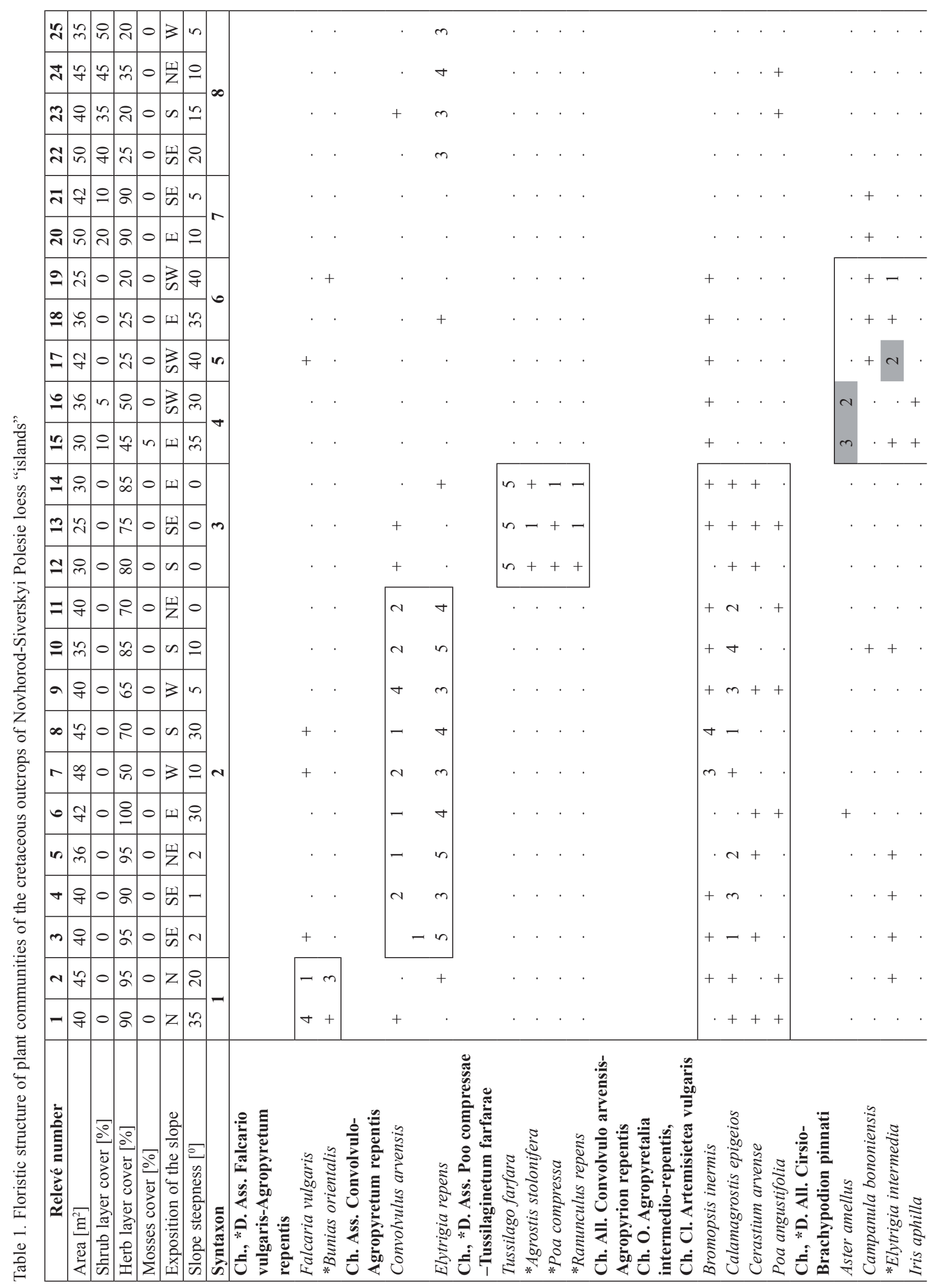



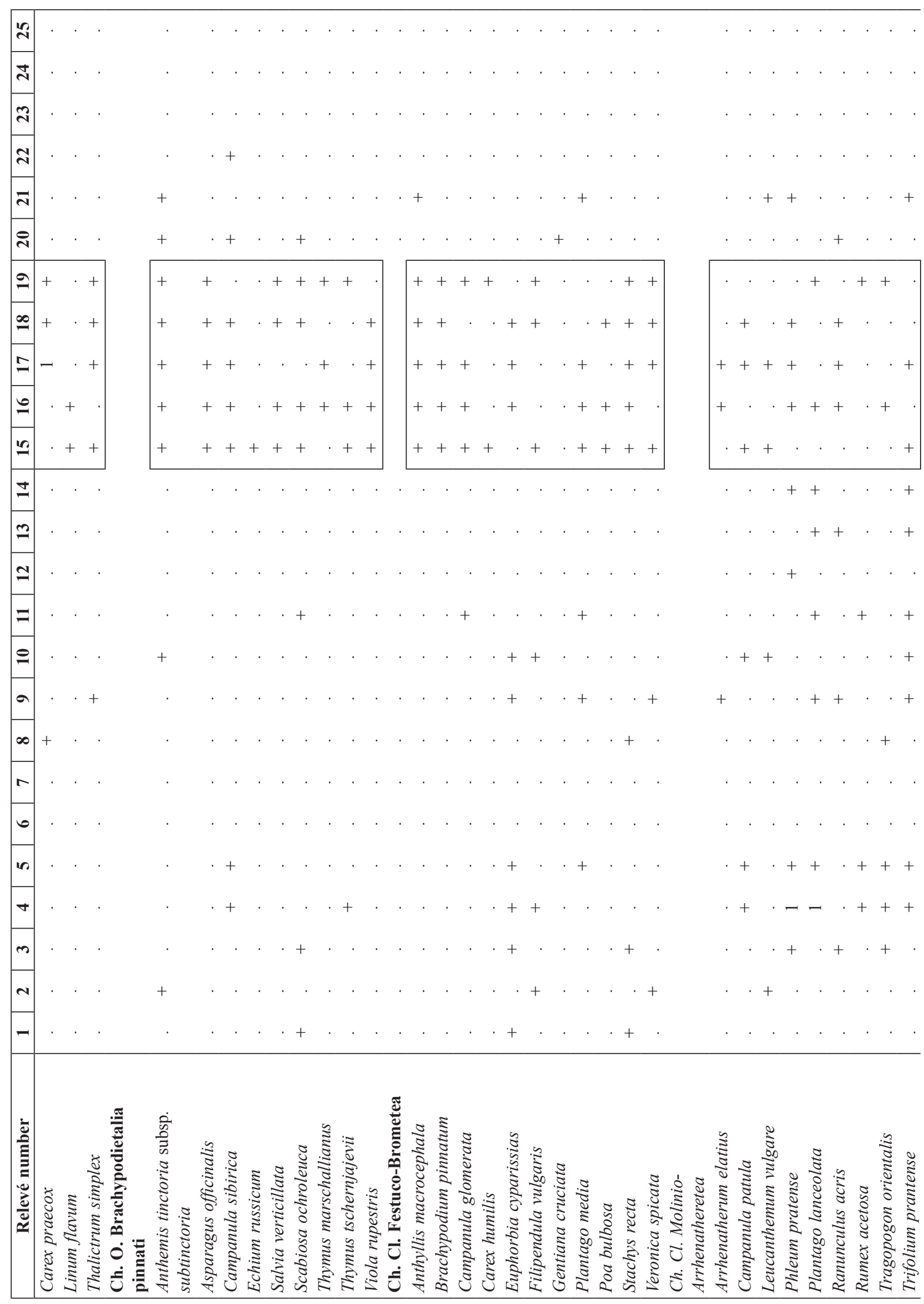


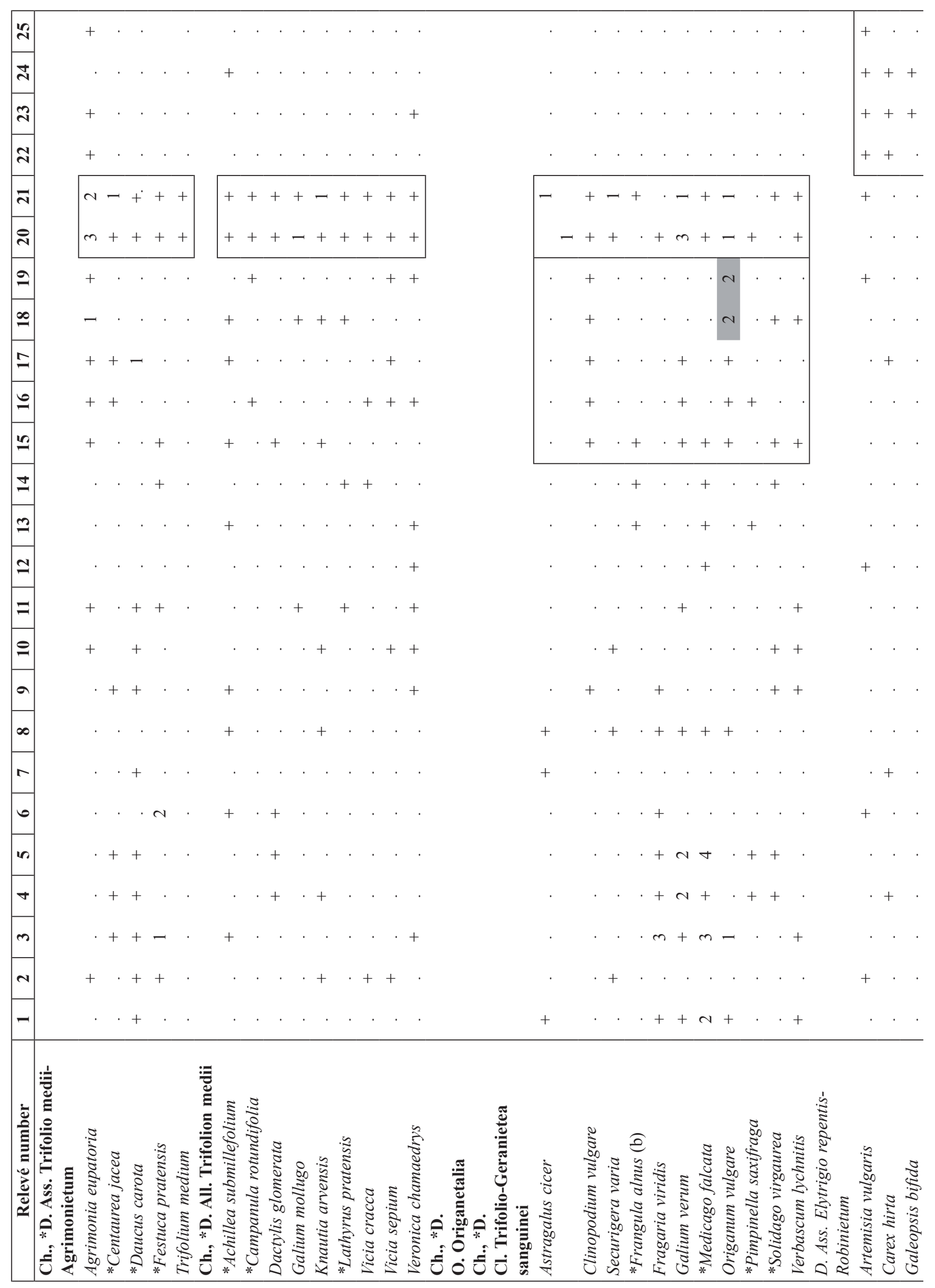




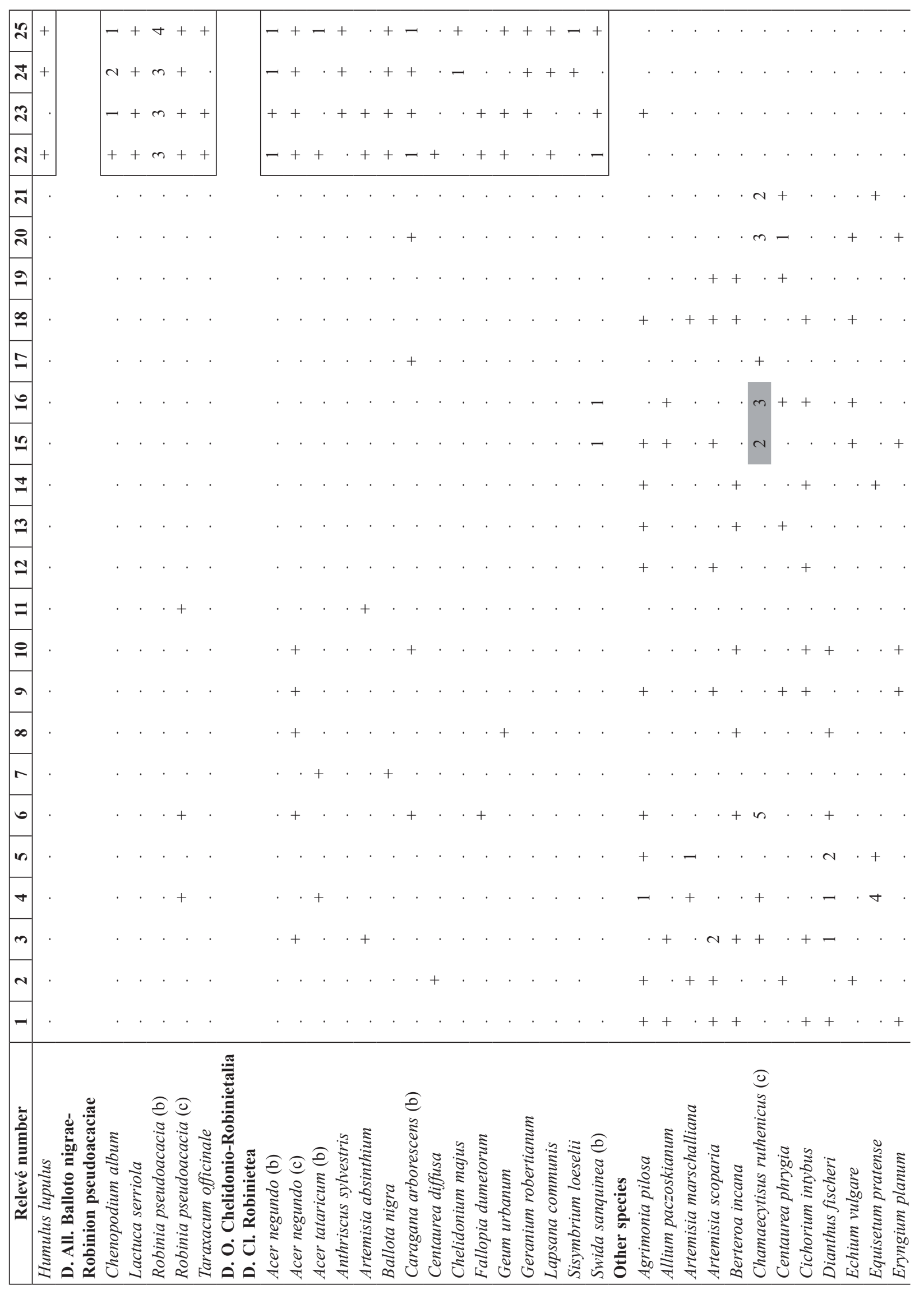




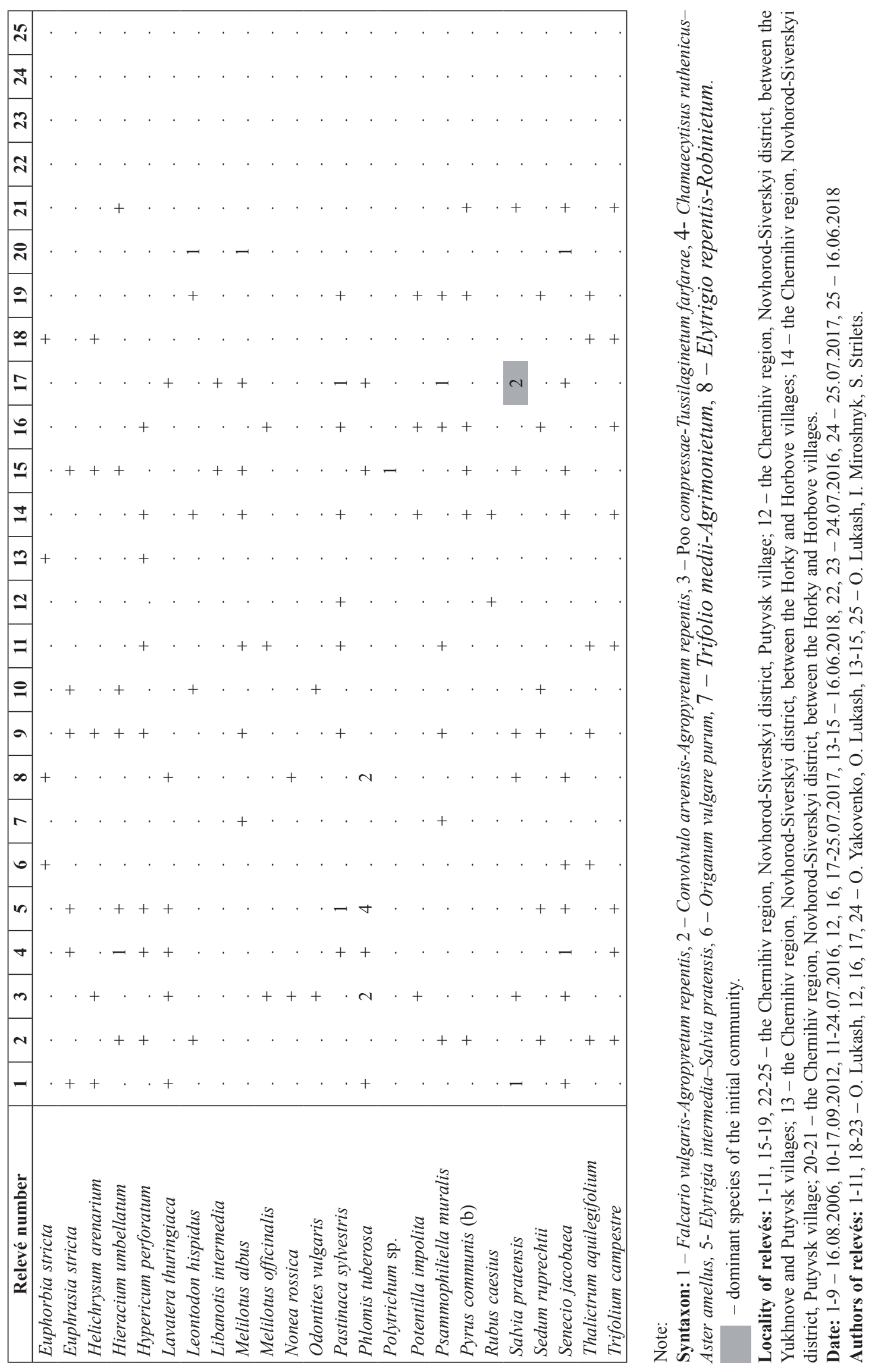


The Convolvulo-Agropyretum repentis phytocoenoses were formed in the areas covered with a $0.5-1.0$-meter layer of loess sediments. These areas were used by the locals 20-25 years ago as kitchen gardens, and now they are experienced such types of anthropogenic influence as cattle grazing and recreational load. The communities are formed by such species as Elytrigia repens (L.) Nevski and Convolvulus arvensis L., sometimes Calamagrostis epigeios (L.) Roth. co-predominates, Cerastium arvense L., Elytrigia intermedia, Poa angustifolia L., P. compressa L. Bromopsis inermis (Leyss.) Holub are singly found. The species of the Molinio-Arrhenatheretea and Festuco-Brometea classes take part in this association communities formation.

Consequently, the Convolvulo-Agropyretum repentis ruderal communities described by us, which are characterized by a high participation of biennial or perennial plants, are mostly a succession stage, which is replaced by the community of Sisymbrion officinalis (Class Papaveretea rhoeadis).

The communities, belonging to the Falcario vulgaris-Agropyretum repentis association, occur on the northern slopes near the Putyvsk village (Fig. 2B). These phytocoenoses occupy small "islets" between erosive dams. They are diagnosed by the dominant species of Falcaria vulgaris Bernh. and Bunias orientalis L.

The foot of cretaceous outcrops is occupied by the phytocoenoses belonging to the Poo compressae-Tussilaginetum association (Fig. 2A, B; Table 1, relevés 12-14). As a rule they were formed in the places of industrial and spontaneous mining of chalk. It should be noted that industrial mining of chalk was carried out near the Putyvsk village in the 70's-90's years of the twentieth century. Unauthorized local chalk mining is continued to the present time. Tussilago farfara L. (the characteristic species of the association) dominates in all of the described areas. These communities are also differentiated by Agrostis stolonifera L., Poa compressa L. and Ranunculus repens L. Depending on the time of phytocoenoses formation the areas of the Poo compressae-Tussilaginetum association vary by the number of species. In the areas, where industrial mining of chalk stopped 30 years ago (Table 1, relevé 14), 34 species were recorded, among which rhizome perennials predominate, as well as tree and shrub species (on the level of the grassy tier).

In the absence of anthropogenic pressure, grass communities with traits of steppe phytocoenoses were formed on the steep slopes of the cretaceous outcrops of the eastern and southwest expositions (Fig. 2B; Table 1, relevés 15-19). This is evidenced by the presence of the characteristic species of the Festuco-Brometea class in the described areas, Anthyllis macrocephala Wender, Brachypodium pinnatum (Huds.) P.Beauv., Campanula glomerata L., Carex humilis Leyss., Euphorbia cyparissias L., Filipendula vulgaris Moench, Plantago media L., Poa bulbosa L., Poa compressa L., Stachys recta L., Veronica spicata L. in particular. There are the characteristic species of the Brachypodietalia pinnati order and the Cirsio-Brachypodion pinnati alliance in all the five relevés. However, the structure and (or) composition of the described communities does not allow to clearly refer them to one or another association of the alliance mentioned above. Note that there is a number of species according to which the Molinio-Arrhenatheretea and Trifolio-Geranietea sanguinei classes are diagnosed in relevés 15-19. Probably the phytocoenoses described by us are the communities at early stages of successions with domination of Chamaecytisus ruthenicus (Fisch. Ex Woł.) Klásková and Aster amellus L. (relevés 15-16), Elytrigia intermedia (Host) Nevski and Salvia pratensis L. (relevé 17), as well as Origanum vulgare L. (relevés 18-19). A projective coverage of the dominants is $15-25 \%$ with a total projective cover of $20-50 \%$. As part of these communities, there is a number of rare for Polesie species that are situated in this region on the northern border of distribution. For example: Aster amellus L., Carex praecox Schreb, Echium russicum J.F. Gmel, Iris aphilla L. and Linum flavum L., Salvia verticillata L., Phlomis tuberosa L. and others. Thus, the recorded xerothermophilic communities have an environmental significance and are the objects of monitoring researches.

Xerothermic and semixerothermic steppe communities in Polesie are rare. For the Western Polesie within the borders of Belarus, Poland and Ukraine (Fijałkowski et al., 2002), as well as the "Prybuzhskoe Polesie" Biosphere Reserve (Demyanchik, 2006), the presence of xerothermic grass communities of the Festuco-Brometea class on the cretaceous sediments is indicated. Such communities are not mentioned for the Polesie National Park (Baryla et al., 2002; Święs, 2002) and Polesie Natural Reserve (Vorobyov et al., 1997). Within Ukrainian (Southern) Polesie the Festuco-Brometea steppe communities are known in Zhytomyr Polesie near the rivers, where crystalline sediments are lying off (Onishchenko, 2006). But they have not been studied in detail. The communities of the Festuco-Brometea class in the Briansk region (Russia) within the boundaries of the loess plateau landscapes in the western spurs of the Middle Russian Highlands, where they are on the northern border of their habitat (Bulokhov, 2001, 2009) have been investigated to the greatest extent. Within Eastern Polesie these are the closest xerothermic phytocoenoses in the cretaceous sediments to the communities described by us. On the territory of the Briansk region, in the composition of the Festuco-Brometea class one Festucetalia valesiacae Soó 1947 order, Cirsio-Brachypodion pinnati Hadač et Klika in Klika et Hadač 1944 alliance with one Poo compressae-Onobrychidoetum arenariae Bulokhov 1990 association (Bulokhov, 2001) was established. The diagnostic species of this 
association are Onobrychis arenaria (Kit.) DC. and Poa compressa $\mathrm{L}$. The communities of this association can be found in small sections on the steep eroded slopes of river valleys and gullies on the complex of ravine-gully gray forest soils spread by chalk. The comparison of phytocoenotic data makes it possible to note that the communities described by A. Bulokhov $(2001,2009)$ differ from the xerothermic phytocoenoses on the cretaceous sediments of Novhorod-Siverskyi Polesie with a greater representation of steppe species.

In relevés 20 and 21 (Table 1), taked out at the chalk outcrops near the Horky village, the characteristic species (Astragalus cicer L., Clinopodium vulgare L., Securigera varia (L.) Lassen, Origanum vulgare, Verbascum lychnitis L.) and diagnostic species (Frangula alnus Mill., Medicago falcata L., Pimpinella saxifraga L.., Solidago virgaurea L.) of the Trifolio-Geranietea class and the Origanetalia order were identified. The described community is referred to the Trifolion medii alliance due to the presence of a number of diagnostic species, among which are the species of the specified alliance: Agrimonia eupatoria L., Galium mollugo L., Trifolium medium L., Vicia sepium L., and the typical species of the Molinio-Arrhenatheretea class (Achillea submillefolium Klokov et Krytzka, Campanula rotundifolia L., Dactylis glomerata L., Knautia arvensis (L.) Coult., Lathyrus pratensis L., Veronica chamaedrys L., Vicia cracca L. et al.). Its belonging to the group of the neutrophilic associations shows the presence of Geranium sylvaticum, Medicago falcata L., Securigera varia. A. Brzeg (2005) points out the characteristic (Agrimonia eupatoria, Trifolium medium L.) and differential (Centaurea jacea L., Daucus carota L., Festuca pratensis Huds. \& Potentilla reptans L.) species for the Trifolio medii-Agrimonietum association. All these species, except the last one, were recorded in the phytocoenoses described by us. That is why we referred these communities from relevés 20 and 21 to the specified association.

In the outskirts of the Putyvsk village on the slopes of the cretaceous outcrops scrub communities of temperate Europe, represented by non-typical for Polesie synanthropic Elytrigio repentis-Robinietum phytocenoses, which are characteristic of the Steppe zone of Ukraine, were formed (Fig. 2B; Table 1, relevés 22-25). These communities are formed by Robinia pseudoacacia L. (3-4 m high) with an admixture of Acer negundo L. The reason for referring the identified communities to the corresponding association is the presence of the diagnostic species (Chenopodium album L., Lactuca serriola L., Taraxacum officinale Wigg. Aggr.) of the Balloto nigrae-Robinion pseudoacaciae Hadač et Sofron 1980 association and the diagnostic species (Elytrigia repens (L.) Nevski with a $20-40 \%$ projective covering, as well as Artemisia vulgaris L., Carex hirta L., Galeopsis bifida Boenn. Humulus lupulus L.) of the Elytrigio repentis-Robinietum association.
We believe that the Elytrigio repentis-Robinietum phytocoenoses are the last stage of the overgrowth of the cretaceous outcrops slopes in the succession series: ruderal phytocenoses of nutrient-demanding short-lived winter annual grasses on sandy anthropogenic soils (Sisymbrion officinalis Tx. et al. ex von Rochow 1951) $\rightarrow$ semiruderal grasslands and herblands (Convolvulo-Agropyretum repentis Felföldy (1942) 1943) $\rightarrow$ ruderal shrub communities Elytrigio repentis-Robinietum Smetana 2002).

In chalk outcrops in the community of the Trifolio medii-Agrimonietum association in the area of $50 \mathrm{~m}^{2}$ (Fig. 2A; Table1, relevé 20) the Gentiana cruciata population was determined. The middle density of the population was 0.34 individuals $/ \mathrm{m}^{2}$. It is represented by two compact groups of 3 and 4 generative individuals, the area of $0.5 \mathrm{~m}^{2}$ each, and 10 juvenile individual plants. The plants of other ontogenetic states have not been found. Thus, the population of $G$. cruciata in a new locality can be characterized as incompletely limbed with a left-sided spectrum: juvenile plants predominate. In Fig. 3 the spatial structure of the $G$. cruciata population is represented.

G. cruciata - a European-Southwest Asian foreststeppe relict species, included in the Red Books of the Republic of Belarus (Skuratovich, 2015) and the Briansk region (Evstigneev, 2004). This species is very rare for the Eastern Polesie. The nearest to the identified place is the "Markovsk mountains" (the Briansk region) - the richest in the Eastern Polesie center of the calcephalous flora. For today, our discovery of G. cruciata is the first and only one for Novhorod-Siverskyi Polesie. It should be noted, that G. cruciata is a diagnostic species of the FestucoBrometea Br.-Bl et Tx. ex Soó 1947 class. However, the conditions of the determined location (open slope of the eastern exposition, close occurrence of carbonate rocks) are typical for the location of this species. For comparison, in Western Europe (in particular, in Poland), the locations of $G$. cruciata were found in xerothermic grassland on the southern and south-western slopes of the river valleys in the communities that are characterized by high proportions of species of the Festuco-Brometea, MolinioArrhenatheretea, Trifolio-Geranietea sanguinei and Rhamno-Prunetea classes (Wójcik \& Piątek, 2015, Wójcik, 2018). In Western Pomerania the population of this species was found in Adonido-Brachypodietum pinnati communities for which $G$. cruciata is a characteristic species (Piotrowska, 2010). It is worth noting that the populations of G. cruciata in western localities, in comparison with the populations in Novhorod-Siverskyi Polesie, are larger in size, more numerous and denser. For example, in Brwice population 183 individuals of G. cruciata were found in the area $1200 \mathrm{~m}^{2}$ (Piotrowska, 2010). 1107 individuals of $G$. cruciata were found in Unisław locality, the highest frequency and density was 0.339 individuals $/ \mathrm{m}^{2}$ (KrasickaKorczyńska et al., 2011) 


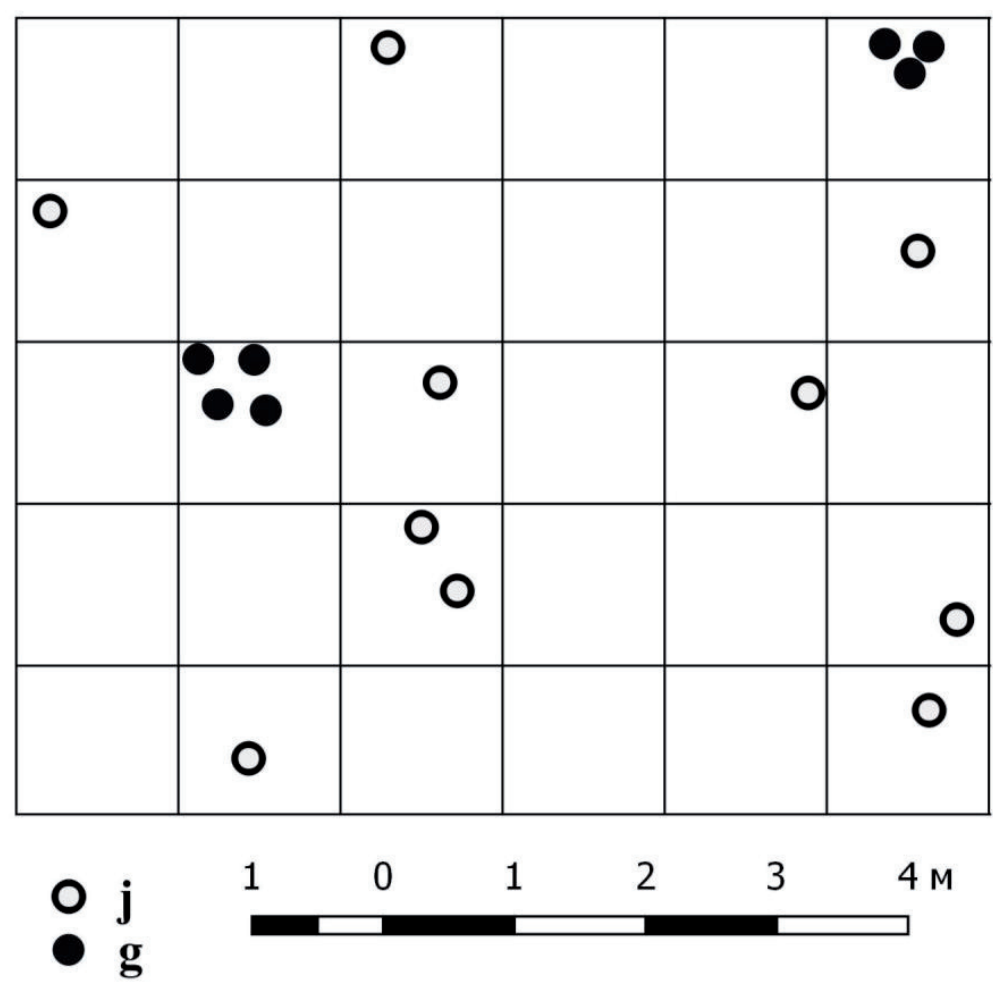

Figure 3. Spatial structure of the G. cruciata population in the Novhorod-Siverskyi locality. Denotations: j - juvenile individuals, $\mathrm{g}$ - generative individuals

The G. cruciata locality in Novgorod-Siverskyi Polesie loess "islands" is not under conservation. Therefore, in order to preserve the habitat of this rare species, it is worth creating here a reserve.

\section{Conclusions}

The structure and composition of the vegetation communities of the cretaceous outcrops of Novhorod-Siverskyi Polesie loess "islands" is influenced by the degree of anthropogenic influence (both in the past and present) on the ecosystems. The determining anthropogenic factors contributing to the formation of the ruderal communities were chalk mining and gardening. The influence of erosive processes is manifested in the spatial delimitation of plant communities of various syntaxonomic belongings.

In the vegetation cover of the cretaceous outcrops of Novhorod-Siverskyi Polesie loess "islands" semiruderal grasslands and herblands phytocoenoses of the nemoral and subboreal zones of Europe belonging to the Convolvulo arvensis-Agropyrion repentis Göors 1967 association predominate. The Elytrigio repentis-Robinietum Smetana 2002 phytocenoses is the last stage of the overgrowth of the cretaceous outcrops slopes during the succession from the ruderal vegetation of nutrient-demanding short-lived winter annual grasses on sandy anthropogenic soils to Robinia groves with weedy understorey on loamy dry soils.

The initial semixerothermic communities (Chamaecytisus ruthenicus-Aster amellus, Elytrigia intermediaSalvia pratensis, Origanum vulgare purum) are close to the phytocoenoses of the Festuco-Brometea class by the species composition. Natural meso-subxerophytic fringe vegetation on nutrient-poor but base-rich soils (Trifolion medii T. Müller 1962) are represented fragmentarily. They do not suffer from the anthropogenic pressure and are separated by erosive forms. Such conditions were favorable for preserving the relict Gentiana cruciata L. species in this locality. The population of this species was found in the area of $50 \mathrm{~m}^{2}$ in the community of the Trifolio medii-Agrimonietum Th. Müller 1962 association and represented by two compact groups of individuals (the area of $0.5 \mathrm{~m}^{2}$ each) and individual plants. In order to preserve the habitat of this rare species, it is worth creating here a reserve. 


\section{References}

Baryła R. \& Urban D., 2002, Ekosystemy łąkowe [Meadow ecosystems], [in:] S. Radwana (ed.), Poleski Park Narodowy [Polesie National Park]. Wydawnictwo MORPOL, Lublin: 201-215.

Brzeg A., 2005, Zespoły kserotermofilnych ziołorośli okrajkowych z klasy Trifolio-Geranietea sanguinei Th. Müller $1962 \mathrm{w}$ Polsce [Xerothermophilous forb fringes and forest edge communities of the class Trifolio-Geranietea sanguinei Th. Müller 1962 in Poland]. Bogucki Wydawnictwo Naukowe, Poznań.

Bulokhov A.D., 2001, Grass vegetation of the South-Western Non-Black Earth Region of Russia. Publishing House of Bryansk State University, Bryansk.

Bulokhov A.D., 2009, Typology of meadows of the Bryansk region. Publishing House of Bryansk State University, Bryansk.

Clarke R.T., Thomas J.A., Elmes G.W., Wardlaw J.C., Munguira M.L. \& Hochberg M.E., 1998, Population modelling of the spatial interactions between Maculinea rebeli their initial foodplant Gentiana cruciata and Myrmica ants within a site. Journal of Insect Conservation 2(1): 29-37.

Demyanchik V.T., 2006, "Pribuzhskoye Polesie" Biosphere Reserve, I.I. Lishtvan (ed.). PH Academy, Brest.

Evstigneev O.I., 2004, Gentiana cruciata L., [in:] Yu.P. Fedotov (ed.), The Red Book of the Bryansk region. Plants. Mushrooms. Chitay-gorod, Bryansk: 201-202

Fijałkowski D., Andrienko T., Onyszenko W., Święs F. \& Urban D., 2002, Ekosystemy lądowe - leśne, kserotermiczne i synantropijne Polesia (Flora i fitocenozy) [Terrestrial and forest, xerothermic, and synanthropic ecosystems of Polesie (Flora and phytocoenoses)]. Acta Agrophysica 66: 147-177.

Krasicka-Korczyńska E., Stosik T. \& Kwiatkowska B., 2011, Zasoby populacji Gentiana cruciata L. na przykładzie murawy kserotermicznej w Unisławiu [Resources of Gentiana cruciata L. population of kerothermic grasslands in Unisław]. Ekologia i Technika 19(6): 333-339.

Korchagin A.A., 2012, Field geobotany. Methodical guidance. E.M. Lavrenko (ed.). PH Ozon.ru, Moscow.

Lukash O., Yakovenko O. \& Miroshnyk I., 2018, The mechanical degradation of land surface and the present state of the loess "islands" plant cover of Chernihiv Polesie (Ukraine). Ecological Questions 29(4): 23-34.

Matuszkiewicz W., 2001, Przewodnik do oznaczania zbiorowisk roślinnych Polski [Guide for determination of Polish plant communities]. Wydawnictwo Naukowe PWN, Warszawa.

Mucina L., Büultmann H., Dierßen K., Theurillat J.-P., Raus T., Čarni A., Šumberová K., Willner W., Dengler J., García R.G., Chytrý M., Hájek M., Di Pietro R., Iakushenko D., Pallas J., Daniëls F.J.A., Bergmeier E.,
Guerra A.S., Ermakov N., Valachovič M., Schaminće J. H.J., Lysenko T., Didukh Y.P., Pignatti S., Rodwell J.S., Capelo J., Weber H.E., Solomeshch A., Dimopoulos P., Aguiar C., Hennekens S.M.\& Tichý L., 2016, Vegetation of Europe: hierarchical floristic classification system of vascular plant, bryophyte, lichen, and algal communities. Applied Vegetation Science 19 (S1): 3-264. (https:// onlinelibrary.wiley.com/doi/epdf/10.1111/avsc.12257).

Marynich A.M. (ed.), 1968, Physical and geographical zoning of the Ukrainian SSR. Publishing House of Kiev University, Kiev.

Onischenko V.A., 2006, Floristic classification of the Ukrainian Polesie vegetation. [in:] T.L. Andrienko (ed.), Phytodiversity of the Ukrainian Polesie and its conservation. Phytosociocentre, Kyiv: 43-84.

Piotrowska J., 2010, Ocena stanu zachowania wybranych populacji goryczki krzyśowej (Gentiana cruciata) na Pomorzu Zachodnim [Evaluation of preservation degree within selected populations of Gentiana cruciata in Western Pomerania]. Folia Pomeranae Universitatis Technologiae Stetinensis, Agric., Aliment., Pisc., Zootech. 278(14): 57-74.

Savon A.P. \& Lysenko H.M., 2001, Ecological and phytoindicative characteristic of plant communities of cretaceous outcrops of Novhorod-Siverskyi Polesie. Ecological state of the Chernihiv region and ways of its optimization: materials of the inter-university student's conference, June 2, 2001. Chernihiv: 21-22.

Skuratovich A.N., 2015, Gentiana cruciata L., [in:] I.M. Kachanovsky, M.E. Nikiforov, V.I. Parfenov (eds), The Red Book of the Republic of Belarus. Plants. Petrus Brovka Belorussian Encyclopedia, Minsk: 184-185.

Solomakha V.A., Kostylov O.V. \& Sheliah-Sosonko Yu.R., 1992, Synanthropic vegetation of Ukraine. Scientific thought, Kyiv.

Święs F., 2002, Ekosystemy synantropijne [Synanthropic ecosystems], [in:] S. Radwana (ed.), Poleski Park Narodowy [Polesie National Park]. Wydawnictwo MORPOL, Lublin: 216-230.

Vorobyov Ye.O., Balashov L.S. \& Solomakha V.A., 1997, The syntaxonomy of vegetation of the Polesie Natural Reserve. Ukrainian Phytosociologocal Collection 8(1): 6-127.

Wójcik T., 2018, Występowanie Gentiana cruciata (Gentianaceae) w zbiorowisku z Brachypodium pinnatum (Festuco-Brometea) w Bukowej na Pogórzu Strzyżowskim [Occurrence of Gentiana cruciata (Gentianaceae) in a community with Brachypo-dium pinnatum (Festuco-Brometea) in Bukowa (Pogórze Strzyżowskie foothills)]. Fragmenta Floristica et Geobotanica Polonica 25(2): 205-215.

Wójcik T. \& Piątek K., 2015, New locality of Gentiana cruciata L. in the Strzyżowskie Foothills (Western Carpathians). Steciana 19(2): 67-73. 